\title{
Sustainable Skyscrapers: The Standard Bank Centre, Johannesburg
}

\author{
By Christo Vosloo*
}

\begin{abstract}
Over the last 20-30 years there has been a renewed interest in tall buildings and skyscrapers as symbols of growth, affluence and progress. The building and operation of this typology is highly resource-intensive and the failure to create sustainable buildings will have serious implications. The Standard Bank Centre in Johannesburg is one of a handful of 'upside-down' or hanging buildings in the world. It was designed to be a prestige symbol in a city that, at the time, was one of the fastest growing cities in the world. Johannesburg is situated on the edge of the world's largest known gold reserve and the associated wealth lead to a city that grew rapidly. The main aim with the design of the building was to create a symbol of the success of its owners, as is the case with many of the skyscrapers constructed in recent times. While the building functioned as intended for a number of years, the owners started planning new accommodation within just seven years and eventually moved out of the building. Sadly, the building stands virtually deserted and derelict and studies have found that it will be very expensive to refurbish this iconic structure. There is a chance that all the energy (physical and human) that went into it may be lost. This is something that must be prevented, here and elsewhere. While the development of the building took place before sustainability or green design became an issue, a retrospective analysis will be undertaken in an effort to corroborate the principles of sustainable or green building and urban design. The aim is to determine if green design should play a role in sustainable investment, and what caused the unsustainability in this case, in order to prevent situations like this recurring in future skyscraper developments.
\end{abstract}

\section{Introduction}

Skyscrapers have been described as a "machine that makes the land pay."1 Ken Yeang defines skyscrapers as "the large high-rise intensive building-type, generally regarded as being over 10 storeys, and which can be of commercial, residential, hotel or mixed use."2 The skyscraper archetype emerged with the onset of the industrial revolution when it became possible to mass manufacture many of the components that made this building-type possible. As this buildingtype became more common, particularly since the end of the Second World War, skyscrapers became the new topographic reference points ${ }^{3}$ and the

\footnotetext{
*Associate Professor, Graduate School of Architecture, University of Johannesburg, South Africa.

1. Cas Gilbert quoted in E. Höweler, Skyscraper: Designs of the Recent Past and for the New Future (London: Thames \& Hudson, 2003), 12.

2. K. Yeang, The Green Skyscraper: The Basis for Designing Sustainable Intensive Buildings (Munich: Prestel Verlag, 1999), 15.

3. A. Lepik, Skyscrapers (Munich: Prestel, 2008), 4.
} 
quintessential building-type of the previous century. It also became a celebration of technology and innovation, particularly structural innovation. ${ }^{4}$ Adrian Smith ${ }^{5}$ holds that skyscrapers make us look up while walking down city streets. To him, "like towering divas, skyscrapers command the urban stage, holding us enthralled yet half-fearing their next majestic manifestation".

Lepik $^{6}$ believes that they have replaced church towers as skyline pinnacles and new reference points in our cities. He continues, saying that skyscrapers reflect the apparent limitless potential of technology to provide the cities of the future. As such, the relationship between skyscrapers and sustainable design has become a frequent topic in the academic conversation regarding this building type. Authors such as Ken Yeang, ${ }^{7}$ Stephen Del Percio, ${ }^{8}$ Steve Watts ${ }^{9}$ and Kheir Al-Kodmany ${ }^{10}$ have addressed this topic in recently published works. Prominent architects have included sustainability in the skyscrapers they have designed. Here London's Swiss Re Headquarters building by Norman Foster and Partners is a case in point. Built at the turn of the century as one of the city's first highrise buildings of recent times, it not only symbolises the changes in urban planning but also the need to design buildings that are more environmentally sensitive, using natural forces to achieve conditions that older buildings could only provide through the use of man-made energy ${ }^{11}$. While this building is not noted for its height, the same period saw a global competition between cities and countries to have the highest buildings. The Burj Khalifa by Skidmore, Owings and Merrill (completed 2010, 828m), the Ping An Finance Centre (completed 2015, 660m) by Kohn Pedersen Fox Associates, the Shanghai World Financial Centre also by Kohn Pedersen Fox Associates (completed 2008, 492m) and Jeddah's Kingdom Tower by Adrian Smith and Gordon Gill Architecture (completed 2019, $1000 \mathrm{~m}$ ) being cases in point. ${ }^{12}$

At the same time, other emerging economies strove to have the most significant or iconic skyscrapers as symbols of their new-found wealth and

4. Höweler, Skyscraper: Designs of the Recent Past and for the New Future, 2003, 12.

5. In J. Duprè, Skyscrapers: A History of the World's Most Extraordinary Buildings (New York: Black Dog \& Leventhal, 2013), 6.

6. Lepik, Skyscrapers, 2008, 4.

7. Yeang, Designing with Nature: The Ecological Basis for Architectural Design (New York: Mcgraw-Hill, 1995); Yeang, The Green Skyscraper: The Basis for Designing Sustainable Intensive Buildings, 1999; Yeang, The Green Skyscraper: The Basis for Designing Sustainable Intensive Buildings (New York: Prestel, 2000); Yeang, Reinventing the Skyscraper: A Vertical Theory of Urban Design (Chichester: Wiley Academy Press, 2002); Yeang, Eco Skyscrapers Volume 1 (ed.) Ivor Richards (Victoria: Images Publishing, 2007); Yeang and L. Bullivant, Eco Skyscrapers Volume 2 (Victoria: Images Publishing, 2011).

8. S. T. Del Percio, "The Skyscraper, Green Design and the LEED Green Building Rating System: The Creation of Uniform Sustainable Standards for the $21^{\text {st }}$ Century or the Perpetuation of an Architectural Fiction," in Environs: Environmental Law and Policy Journal 28, no. 1 (2004): 117-154.

9. S. Watts, "Can Skyscrapers be Sustainable?" in The Council on Tall Buildings and Urban Habitat Journal 2, no. 68 (2013). 2015).

10. K. Al-Kodmay, Eco-Towers: Sustainable Cities in the Sky (Southhampton: WIT Press,

11. Lepik, Skyscrapers, 2008, 132.

12. Duprè, Skyscrapers: A History of the World's Most Extraordinary Buildings, 2013. 
prominence. Examples include the CCTV Headquarters in Beijing by OMA (completed 2008), Shanghai Tower by Gensler (completed 2015), the Petronas Towers in Kuala Lumpur (completed 1998) by Cesar Peli and Associates and some less prominent examples such as the Taipei 101, Endless Dubai, Jin Mao Tower and the Burj al Arab. ${ }^{13}$

Not to be outdone, developed economies responded with a number of prominent skyscrapers. Examples include 53W53RD in New York by Jean Nouvel (completed 2018), The One World Trade Centre in New York by Skidmore, Owings and Merrill (completed 2014), The Shard in London by Renzo Piano Workshop (completed 2012) and the International Commerce Centre in Hong Kong by Kohn Pedersen Fox Associates (completed 2010), amongst many others. $^{14}$

The development of the skyscraper typology was based on a number of factors. The first of these are developments in structure and technologies, including the ability to build higher, move people through these buildings, install services and improve the interaction with the natural environment. ${ }^{15}$ Another aspect is commercial interests, which in turn are linked to the raised status of the firm, a city or a country, because buildings of this nature rarely provide a rapid return on investment. ${ }^{16}$ However, skyscrapers are increasingly seen as a solution to the problems caused by rapid urbanisation and as such, skyscrapers will increasingly be constructed. However, there exist questions about the proliferation of this building-type in the light of sustainability or green requirements, considering the costs of tall buildings in energy and natural resources are higher. ${ }^{17}$ However, as Yeang points out, those who regard skyscrapers as "energy-hungry parasites" 18 are not looking at the entire life-cycle of the building, in addition to the larger interrelated web of human and environmental systems. He holds that the possibility of eventually recycling these materials is far greater in the case of skyscrapers. ${ }^{19}$ Furthermore, he holds that the increased densities, and concomitant compact cities, affirm skyscrapers as a viable substitute to the low-rise, spread-out alternative, often associated with green architecture. This view is supported by Sassi who points to the fact that land constitutes a limited resource that must be used conservatively. ${ }^{20}$

The Standard Bank Centre in Johannesburg (Figure 1) incorporates the key attributes of the skyscraper typology: It was conceived and initiated (as will be

13. Duprè, Skyscrapers: A History of the World's Most Extraordinary Buildings, 2013; Lepik, Skyscrapers, 2008; I. Zaknic, M. Smith, D. Rice, 100 of the World's Tallest Buildings (Victoria: Images Publishing, 1998).

14. Ibid.

15. Lepik, Skyscrapers, 2008, 5.

16. Lepik, Skyscrapers, 2008, 23; Duprè, Skyscrapers: A History of the World's Most Extraordinary Buildings, 2013, 6.

17. A. B. Gültekin and S. Yavaşbatmaz, "Sustainable Design of Tall Buildings," in Gradevinar 65, no. 5 (2013): 450.

18. Yeang, The Green Skyscraper: The Basis for Designing Sustainable Intensive Buildings, 1999, 18.

19. Ibid, 19.

20. P. Sassi, Strategies for Sustainable Architecture (New York: Taylor \& Francis, 2006), 12. 
shown) to solve urban problems in a rapidly developing city, and as a symbol of the wealth and economic achievement of its owners. As the project developed, technological and structural challenges were solved in innovative ways which were at the cutting edge of skyscraper building technology. Despite this, the building stands virtually deserted now and by and large unused, yet is still acknowledged as one of the iconic buildings of Johannesburg. However, unless the designers of future skyscrapers learn from the sad fate of this building, more of today's skyscrapers might befall a similar fate.

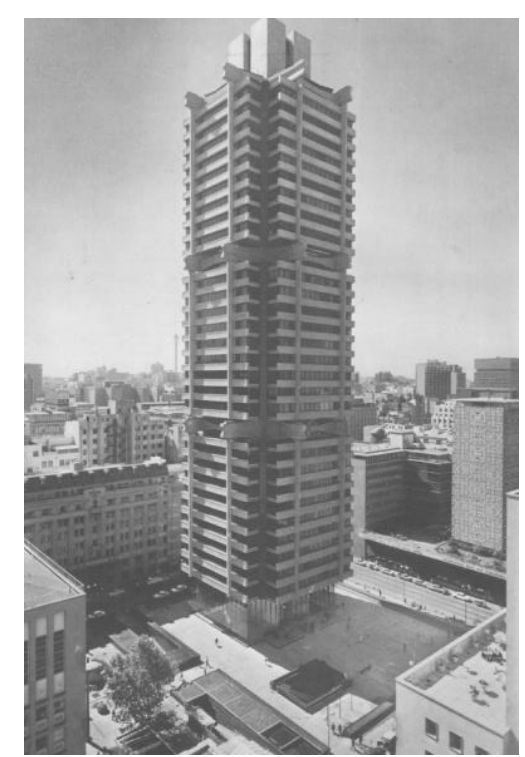

Figure 1. The Standard Bank Centre

Source: J.G. Boss from Hentrich 1970, 48.

Based on a literature review and augmented by an interview with one of the architects responsible for this building, this paper will firstly consider hanging buildings as a phenomenon that took place during the late-modern period. The design and construction of this example will then be discussed. Thereafter, its layout and form will be analysed from a sustainability point of view. This is done in an effort to determine possible indications as to why this building is standing largely unused. Because skyscrapers are seen by some as an appropriate response to the environmental crisis, it is pertinent that we analyse examples of this typology to discover the lessons that we can learn from past projects, in order to avoid repeating these mistakes in future buildings. The natural and financial resources captured by every new building make it imperative that we continue cautiously as we venture on. 


\section{Principles of Sustainable or Green Design}

In general terms, sustainability is understood as "the quality of being able to continue over a period of time." ${ }^{21}$ This attribute is crucial when considering a building from a cost point of view, just as 'sustainability' is important from an ecological or environmental point of view. While no general accepted definition for sustainable development exists, one of the more important definitions is the so called Bruntland definition which holds that it is "development that meets the needs of the present without compromising the ability of future generations to meet their own needs." 22 Sustainable design has in turn been defined by Foster and Partners as "creation of buildings which are energy efficient, healthy, comfortable, flexible in use and designed for a long life." "23 Another definition is "environmentally conscious, energy saving and utilises responsive and renewable materials and systems." 24 The impact of buildings, particularly skyscrapers, and the importance of sustainable design are underscored by Sassi ${ }^{25}$ who reminds us that "no matter how energy- and water-efficient a building might be, it becomes a waste of resources and a potential detriment to the community if no one wants to occupy it". With this statement she links the fields of sustainability and usability, two aspects that are keys to this study.

The need for designs that are flexible and can easily adapt to changing circumstances, practices, requirements and technologies, introduced in Foster and Partners' definition (above), is also articulated by Sassi who explains that in order to ensure the long-term usage of a building, it is essential to provide a building that can accommodate changes in purpose and context and that is built from materials that are durable, and easily maintained and upgraded. ${ }^{26}$

\section{Hanging Buildings}

According to Charles Jenks, Modern architecture finally died July 1972 (even though the process started in 1967. $)^{27}$ Jenks holds that the death of Modern architecture led to a relatively brief period which he termed Late-Modern architecture. He describes Late-Modern architecture as 'single-coded' architecture which reuses the elements of the Modern movement at a new level - one where these ideas and forms are taken to "...an extreme, exaggerating the structure and

21. Cambridge Dictionaries, Cambridge Business English Dictionary (Cambridge University Press [s.a.]).

22. B. Edwards, Rough Guide to Sustainability: A Design Primer. $4^{\text {th }}$ Edition (London: RIBA Publishing, 2014), 28.

23. Ibid.

24. Newman in M. M. Ali and P. J. Armstrong, "Overview of Sustainable Design Factors in High-Rise Buildings," Paper Delivered at Council on Tall Buildings and Urban Habitat $8^{\text {th }}$ World Congress, Dubai, 2008, 2.

25. Sassi, Strategies for Sustainable Architecture, 2006, 9.

26. Ibid, 49. 1980), 6 .

27. C. Jenks, Late-Modern Architecture and Other Essays (London: Academy Editions, 
technological image of the building in an attempt to provide amusement, or aesthetic pleasure." ${ }^{28}$ He regards Norman Foster's Sainsbury Centre (1974-8) and Piano and Rogers' Pompidou Centre (1971-77) as prime examples of this period. To him, this period started in 1960 and continued in parallel to Post-Modernism. ${ }^{29}$

One of the manifestations of this movement was the so-called 'hanging buildings' which were constructed over the period 1969-1985. While suspended structures were not new, this period saw it given new prominence in the way of Late-Modernism. Some of the buildings and structures constructed in this way during this period include the Westcoast Transmission Tower in Vancouver by Rhone and Iredale (1969), BMW Headquarters, Munich by Karl Schwanzer (1973), Standard Bank Centre, Johannesburg by Hentrich and Petschnigg (1970), Munich Olympic Stadium by Frei Otto (1972), Federal Reserve Bank, Minneapolis by Gunmar Birkets (1973), Hypo Bank, Munich by Bea and Walter Betz (1980) and the Hong Kong Shanghai Bank by Norman Foster $(1986)^{30}$ (Figure 2).

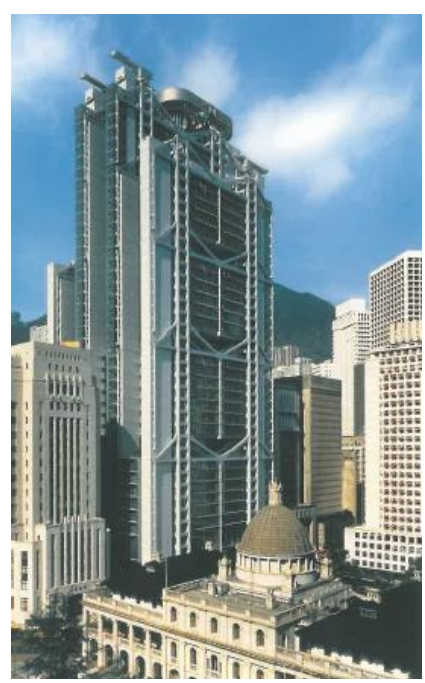

Figure 2. Shanghai Bank Headquarters, Hong Kong

Source: Ian Lambot in Lepik 2008, 106.

The advantages associated with this type of structure are: ${ }^{31}$

- There are no columns on the ground floor and no load-bearing walls are required. If the ground floor is enclosed in glass, there is no visual obstruction between the building and its surroundings. This was one of the main reasons why this type of structure was chosen for this building.

- The useable floor area of each floor is maximised resulting in enhanced feasibility and a reduction in perimeter walling.

28. Ibid, 8 .

29. Ibid, 32.

30. G. D. Schierle, Suspend High-Rise (2012); Archdaily, Munich Olympic Stadium (2018); Duprè, Skyscrapers: A History of the World's Most Extraordinary Buildings, 2013, 92.

31. G. J. Zunz, R. A. Heydenrych, D. Michael, "The Standard Bank Centre, Johannesburg," in Die Siviele Ingenieur in Suid Afrika (February 1971), 30. 
- The sectional area of the hangars is smaller than what columns would have been, leading to better space utilisation.

- The areas that carry the loads down to ground level are heavily prestressed and therefore more able to resist bending moments caused by lateral forces.

As will be described in more detail, the Standard Bank Centre was typically built from the top down. The central core containing services and vertical movement spaces were built first, and thereafter three sets of cantilever beams were constructed from this core. The floors were constructed from the top down, suspended by prestressed concrete hangars from the cantilever beams.

\section{Research Methodology}

A qualitative approach comprising a literature review and interview were used as part of this approach. The project architect was interviewed and research comprising books and other sources was undertaken. The building and the construction process are well documented. Unfortunately, almost all the literature on it hails from the 1970s. However, this does not affect their usability for this study.

Boote and Beile ${ }^{32}$ consider that, "A thorough, sophisticated literature review is the foundation and inspiration for substantial, useful research". Many others, including Combs, Bustamante \& Onwuegbuzie (2010), Onwuegbuzie, Collins, Leech, Dellinger \& Jiao (2010) affirm that literature reviews can form a very important step in research. ${ }^{33}$

\section{Context}

Gold was discovered at the place where Johannesburg was to rise in $1886 .^{34}$ The extent of the discovery led to a rapid process of development and growth, causing Carl Jeppe to write in 1906, "Those who marvel at Johannesburg, who stand amazed at the energy and enterprise which called up a city of a hundred thousand inhabitants, equipped with all the advantages of modern civilisation, where ten or twelve years previously there had been only the lonely veld, are often not aware that the wonder is even greater than it appears at first sight. For not one but three Johannesburgs were built in that time. First came the primary - the corrugated iron stage; next, the age of one or two storied brick buildings; finally, these were again demolished to make room for edifices of which any

32. D. N. Boote and P. Beile, "Scholars Before Researchers: on the Centrality of the Dissertation Literature Review in Research Preparation," Educational Researcher 34, no. 6 (2005): 5. 33. Ibid, 6.

34. C. M. Chipkin, Johannesburg Style: Architecture and Society 1880s-1960s (Cape Town: David Philip, 1993), 7. 
city might well be proud." 35 The rapid development continued beyond 1906 with development governed by British inspired town planning regulations resulting in congested narrow building sites $(15-30 \mathrm{~m}$ wide) and buildings which were "aggressively different from its neighbour. The whole results in the type of urban nightmare so consistently criticized." 36 The actions of property developers, such as Gotlieb and town planners, such as Professor Wilfrid Mallows, resulted in changes to the 1967 amendment to the Town Planning Regulations. ${ }^{37}$ The revised regulations allowed for higher buildings as a trade-off for the creation of public open space to ease the existing congestion. ${ }^{38}$ While the Standard Bank Centre (1970) was the first building to give expression to the change, it was soon followed by the Carlton Centre (1972) designed by Skidmore, Owings and Merril (SKM), and the IBM Building (1974) by Arup Associates, all within a few city blocks of each other. ${ }^{39}$ The changed regulations furthermore led to 60 tower blocks being constructed in the central business centre of Johannesburg within the next 10 years. ${ }^{40}$ However, what Prof. Mallows and company had not realised was that Johannesburg was running out of steam and that the central area's economy, social mobility and entrepreneurial energy was limited by generations of institutionalised segregation. Social changes would soon see businesses migrate away from the central area towards the northern parts of the city as the demographics started changing in line with political changes. ${ }^{41}$

In order to be allowed a high-rise building (25-30 storeys) the project was restricted to a mere $26 \%$ coverage and the building was placed in the north-eastern corner of the site to minimise the negative influence of its shadow on adjoining properties. $^{42}$

\section{Design Parameters and Process}

Hentrich $^{43}$ recalls that the clients had two objectives namely:

- A prestigious headquarter with national, and possibly international, acknowledgement for themselves.

- An adequate return on their investment.

These objectives can be elaborated on as follows:

35. Extract first published in the Kaleidoscopic Transvaal cited in Chipkin, Johannesburg Style: Architecture and Society 1880s-1960s, 1993, 11.

36. Zunz, Heydenrych, Michael, "The Standard Bank Centre, Johannesburg," 1971, 29.

37. Chipkin, Johannesburg Transition: Architecture and Society from 1950 (Johannesburg: STE, 2008), 136.

38. Ibid.

39. Ibid, 141-152.

40. Ibid, 146.

41. Ibid, 164.

42. H. Hentrich, Standard Bank Centre Johannesburg (Johannesburg: Standard Bank Investment Corporation, 1970), 12.

43. Ibid. 
- To incorporate the branch that the bank had been operating on the site for many years.

- To house the bank's executive offices (and related facilities) and its most important divisions.

- Office space should be of a high standard comparable with international standards.

- Optimising the limits imposed by the Town Planning restrictions. ${ }^{44}$

The first step by Standard Bank was to appoint Professor Mallows as planning consultant in 1963. He was tasked to conduct a series of pre-design studies. ${ }^{45}$ This was an innovative approach, the first of a number of such 'first-offs' associated with this project. ${ }^{46}$ In his report, submitted in 1964, Prof. Mallows examined several options in broad outline. The report strongly argued for the creation of an open space and a tall building that would dominate its neighbours. Furthermore, it recommended that the bank seriously consider that the building should provide a deep space office plan with as many offices as possible situated away from any street and the maximum possible number of parking spaces, and that the lower ground floor should have well-planned access and contain commercial activity. ${ }^{47}$ Because of the client's requirement that the building should offer an adequate return on investment, the pre-design process also required feasibility studies conducted by the appointed quantity surveyors.

The pre-design studies were accepted by the clients and Prof. Mallows suggested that Heintrich-Petschnigg and Partners from Düsseldorf, Germany be appointed as architects. ${ }^{48}$ The firm was renowned for their skyscraper buildings, notably the Dreischeibenhaus (1957-1960) also known as the Thyssen Steelworks Building, still regarded as one of the most noted post-war buildings in Germany. ${ }^{49}$ The Johannesburg firm, Stucke, Harrison, Ritchie and Partners, the practice responsible for all local Standard Bank buildings, were appointed as architects of record. Heintrich-Petschnigg and Partners opened a local office in Johannesburg where all the documentation and detail design occurred. This office later became Hentrich, Bergs and Associates who in turn were responsible for a number of notable Southern African buildings. ${ }^{50}$ Ove Arup and Partners (London-Johannesburg) were appointed as structural engineers. ${ }^{51}$

The design concept was the creation of an open space in the congested urban area. In order to strengthen the effect of the open space, there should be as little obstruction as possible at the ground floor level, the core of the tower

44. Zunz, Heydenrych, Michael, "The Standard Bank Centre, Johannesburg," 1971, 30; Hentrich, Standard Bank Centre Johannesburg, 1970, 16.

45. Zunz, Heydenrych, Michael, “The Standard Bank Centre, Johannesburg,” 1971, 30.

46. Hentrich, Standard Bank Centre Johannesburg, 1970, 16.

47. Zunz, Heydenrych, Michael, "The Standard Bank Centre, Johannesburg," 1971, 30.

48. H. Bergs, Architect. Former Partner in the Firm Heintrich, Bergs and Associates. Personal Interview (Johannesburg, 2 October, 2018).

49. J. Lubitz, Architecten-Portrait: Helmut Hentrich 1905-2001 (2005).

50. Bergs, 2018; Chipkin, Johannesburg Transition: Architecture and Society from 1950, 2006, 168.

51. Hentrich, Standard Bank Centre Johannesburg, 1970, 6. 
excluded. ${ }^{52}$ To this end, the architects managed to persuade the client that the banking hall (of the branch that had operated on the site for years) should be located on a lower ground floor level and that there should be no other shops at ground floor level either. ${ }^{53}$ In order to achieve this, the architects opted for a hanging building structure. ${ }^{54}$ The tower comprised a central core housing all the vertical movement and service distribution areas (Figure 3).

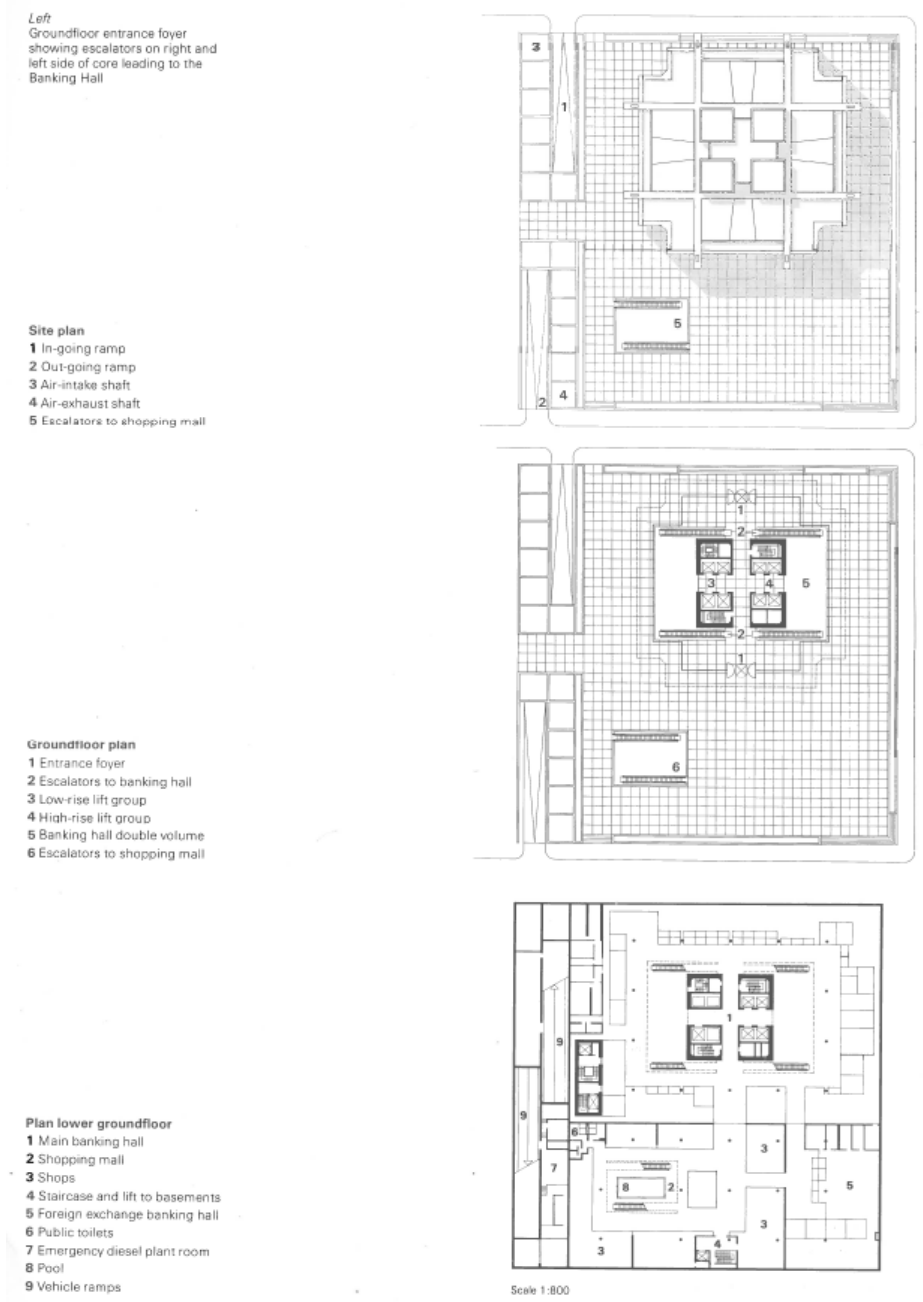

Figure 3. Site, Ground Floor and Lower Ground Floor Plans Source: Hentrich 1970, 15.

The design of the structural system strongly influenced the final form of the building. A conventional suspension system that utilised an umbrella-like structure at roof-level would interfere with the service runs. ${ }^{55}$ This led to the decision to use a prestressed concrete cantilever beam system. Three sets of cantilever beams, acting as brackets, jutted out from the central core. Each set

52. Ibid, 27.

53. Ibid.

54. Ibid.

55. Zunz, Heydenrych, Michael, The Standard Bank Centre, Johannesburg," 1971, 31. 
of cantilever beams supported nine office floors, suspended from it by prestressed concrete hangars. Because of the influence of weight on the size and cost of structural elements, lightweight concrete was used predominantly.

The spaces between the cantilever beams were used to house mechanical plant rooms (Figure 4.) ${ }^{56}$ The soffit of the first floor slab ended at 10.8 meters above ground level, further aiding the spatial character of the design concept.

East'west section through building

1 Parking floors

2 Computer department floor

3 Banking Hall

4 Strong-room tower

5 Entrance foyis

6 Typical offico filoors

7 Mechanical plant roam floor

8 Staff cateteria and kitchen

9 General Managets' floor and directors dining-rooms

10 Directors' floors

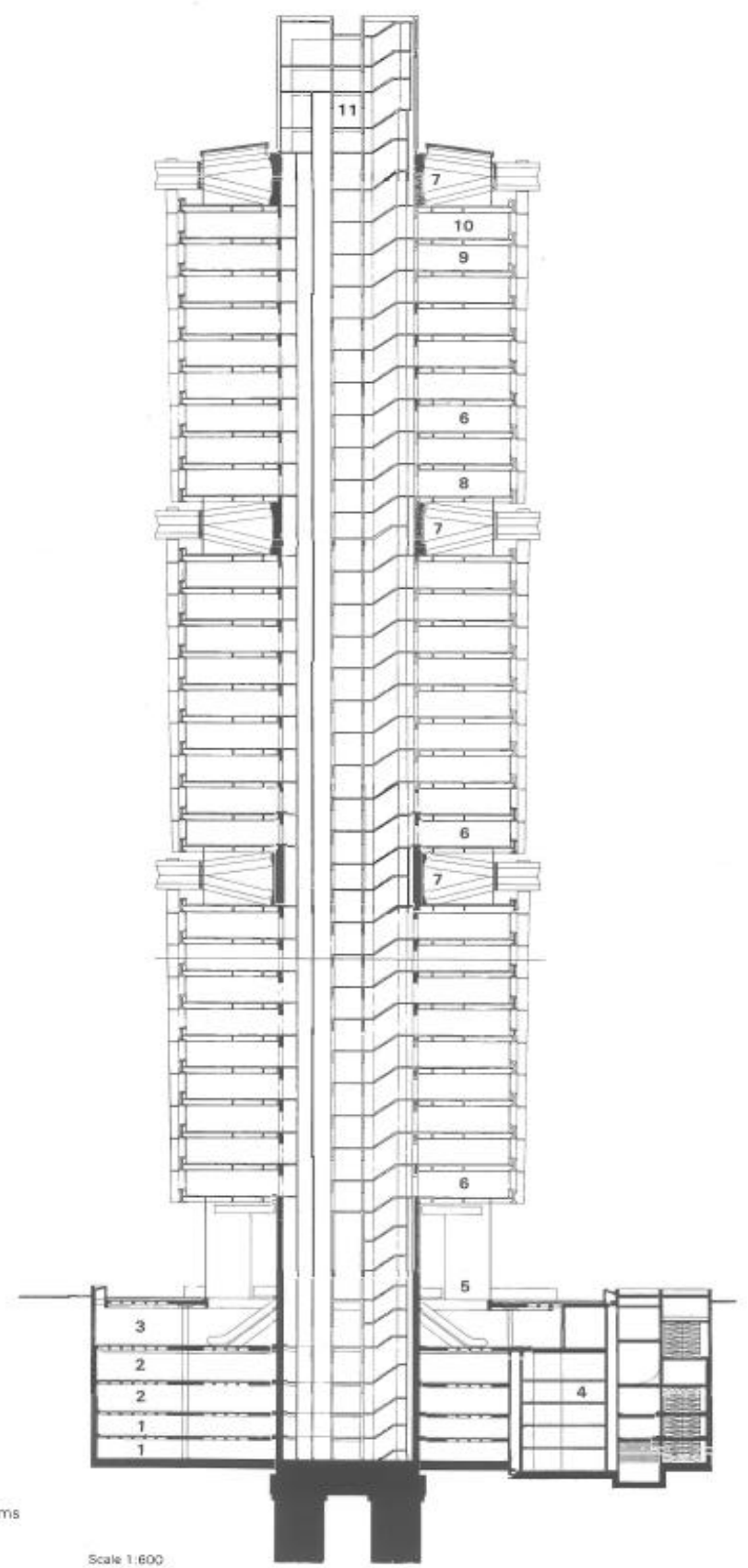

Figure 4. East-West Section through Building

Source: Hentrich 1970, 13.

56. Hentrich, Standard Bank Centre Johannesburg, 1970, 27. 
Vol. 6, No. 1

Typical floor plan

1 Lift lobby

2 Toilets

3 Non-European toilet

4 Cleaners' room

5 Tea-kitchen

Plan cafeteria 19th floo

1 Serving counter

2 Dining area

3 General kitchen

4 Vegetable preparation

5 Cold-room

6 Pot wash

7 Storerocm

8 Supervisor's office

9 Statf change room

10 Wash-up

Plan 27th floor

1 Reception area

2 Board-room

3 General Managers' conference room

4 Ante-room

5 Stair-case to 26 th floor

6 Directors bath room

7 Directors' offices

8 General offices

Figure 5. Office Floor Plans ${ }^{57}$ Source: Hentrich 1970, 17.

57. Ibid, 17.
Vosloo: Sustainable Skyscrapers: The Standard Bank...
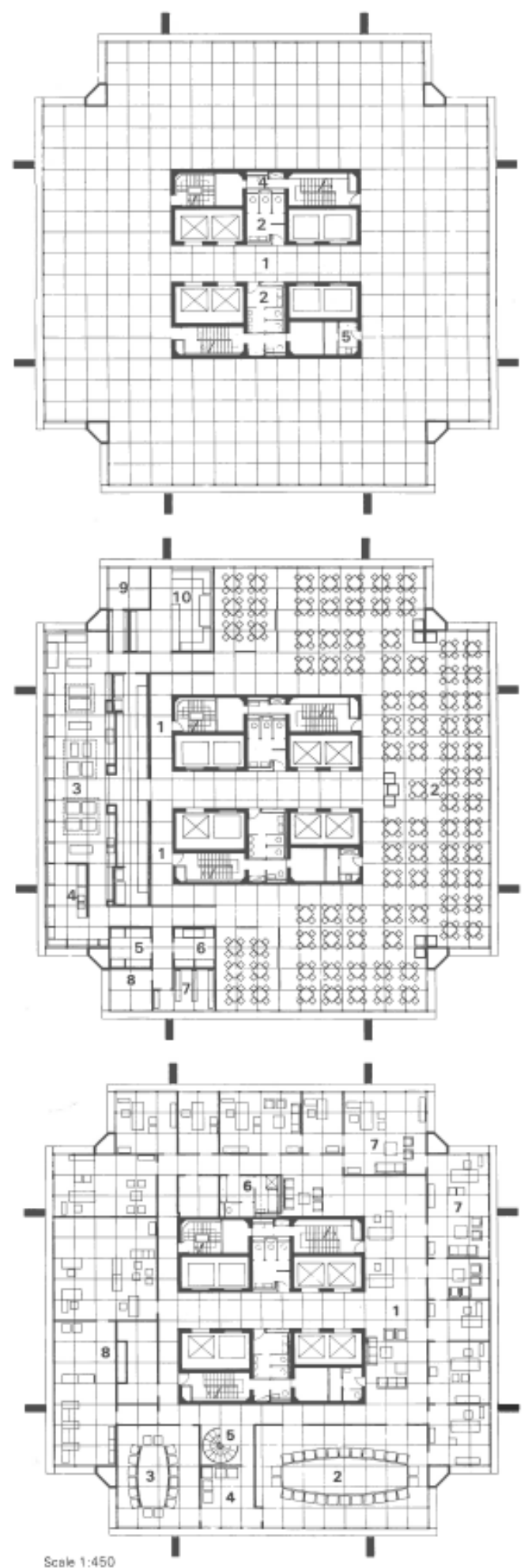

Scab 1:450 
The first basement (or lower ground floor) was given to the banking hall supported by limited retail space. In order to maintain the connection between the lower ground floor and the ground floor (piazza) the two levels were linked by a double volume space that included the foyer area (Figures 3 and 4), while the second and third basement floors accommodated the bank's computer centre with car-parking on the fourth and fifth basement floors. The choice of a hanging structure for the tower block meant that the structural grid for the basement could be decided without having to find a compromise between the requirements of the tower block and the basement. In this way the design concept was realised. The various floorplans are shown in Figure 5. Various images showing the completed building in context are shown in Figures 6-7.

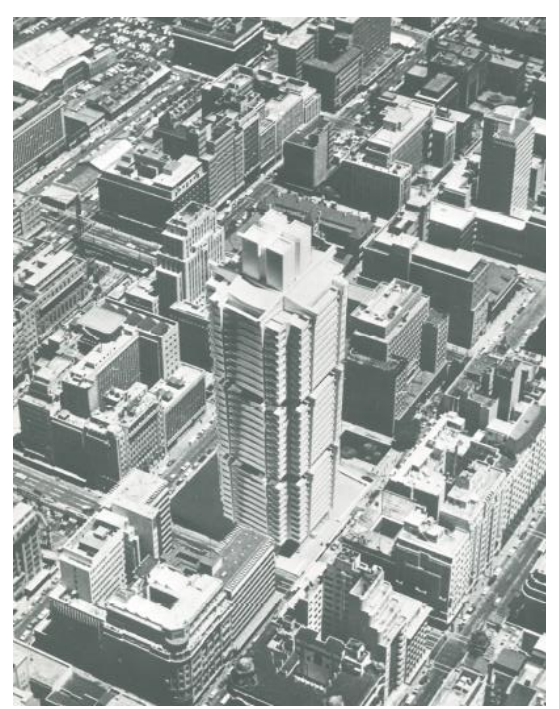

Figure 6. The Standard Bank Centre in Context

Source: Anglo American Photographic Section in Hentrich 1970, [s.p.]

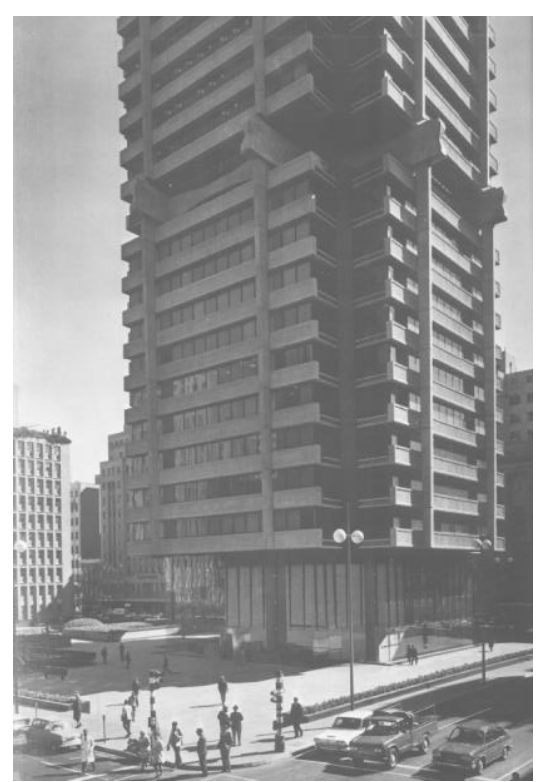

Figure 7. Street-View: Standard Bank Centre

Source: G. Cassel in Hentrich 1970, 22. 


\section{Construction Process}

The bulk excavation for the lower ground and four basement floors was planned in stages to allow for the earliest possible start to the central core structure. Work on these foundations started as soon as the excavations were completed. ${ }^{58}$ Technology developed by the local mining industry was put to use in the construction of the four large diameter shafts (5.03 meters in diameter) ${ }^{59}$ which house the piles that support this section (Figure 8). After completion, the four shafts were capped with a raft that would receive all the loads from the tower structure.

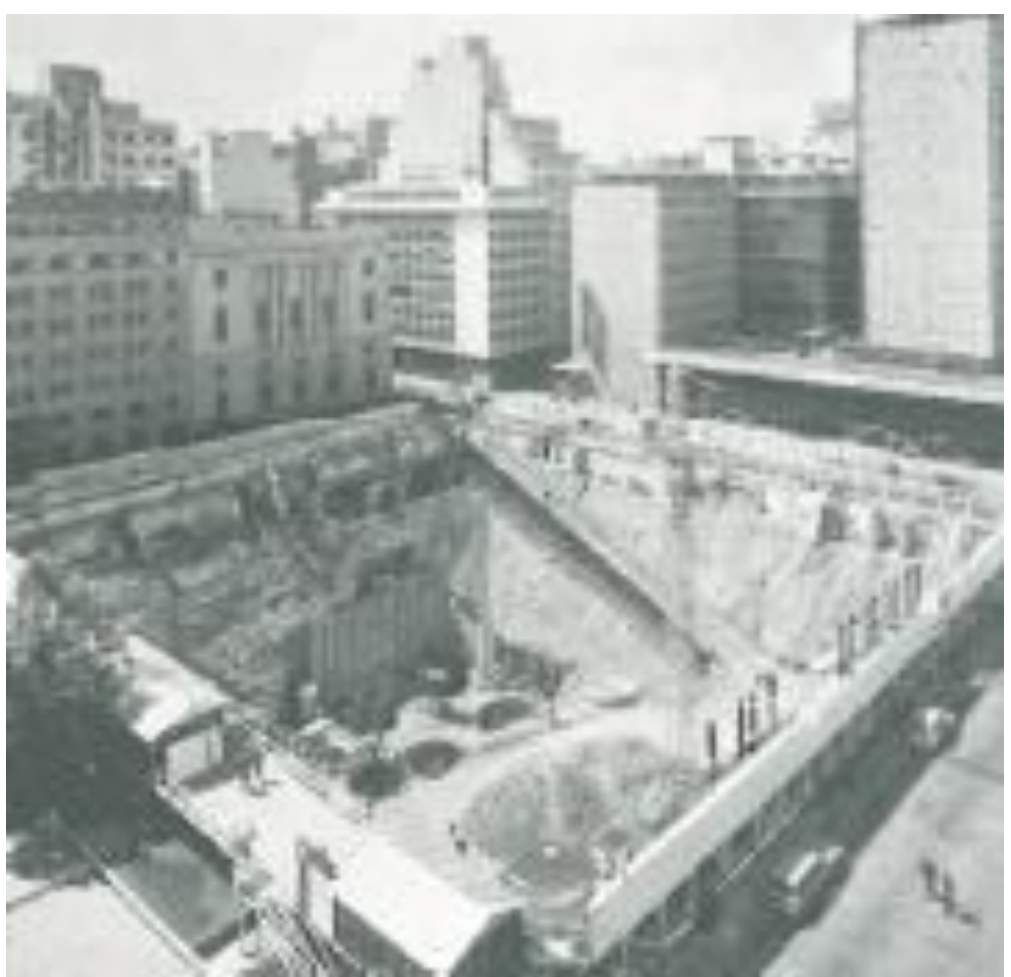

Figure 8. Progress Photograph: March 1967

Source: J.G. Boss from Hentrich 1970, 44.

Next the $158.5 \mathrm{~m}$ high service and movement core was cast using sliding formwork. The process was complicated by the requirement to provide for the subsequent attachment of the floor slabs and the cantilever beams (Figures 9 and 10). During this time the excavation of the remainder of the basement floors continued.

58. This section is based on Hentrich, Standard Bank Centre Johannesburg, 1970, 33-51. 59. Zunz, Heydenrych, Michael, The Standard Bank Centre, Johannesburg,” 1971, 33. 


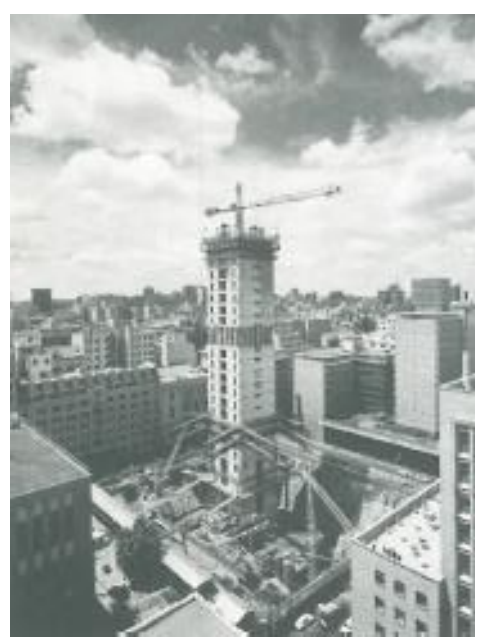

Figure 9. Progress Photograph: October 1967 Source: J.G. Boss from Hentrich 1970, 44.

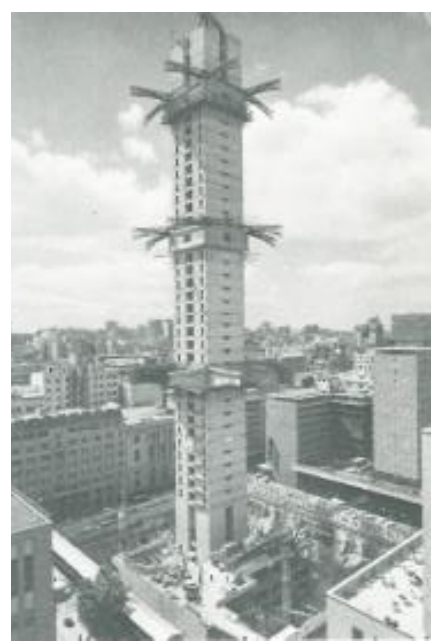

Figure 10. Progress Photograph: March 1968 Source: J.G. Boss from Hentrich 1970, 45.

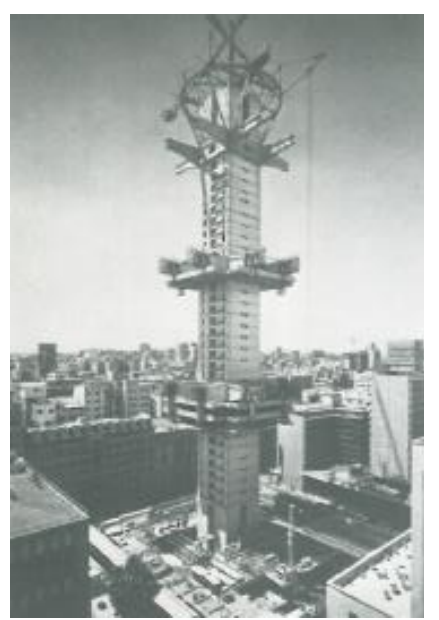

Figure 11. Progress Photograph: October 1968 Source: J.G. Boss from Hentrich 1970, 46. 
The lifting of the precast and other components was done by means of a 68.9ton double boom crane placed at the top of the central core (Figure 11).

Hereafter the three cantilever brackets were constructed. According to Hentrich, this was arguably the most difficult part of the process. This was accomplished by progressively building out from the core, using the completed section as support for the next section. After completion the cantilever beams were prestressed in stages to match the load applied by the cumulative floors as they were constructed. The floors were constructed from the cantilevers downwards, starting with the highest floor and adding floors downwards. The hangars were constructed from precast, prestressed concrete panels and supported four precast, prestressed perimeter beams (one on each side of the building). The floors were supported by these beams and the central core. The three banks of floors were constructed simultaneously resulting in substantial time savings (Figure 12). The floors were also constructed from precast, prestressed concrete panels.

The installation of the remaining components forming the building envelope, and the various services and finishes took place as the structure took shape (Figures 12-14).

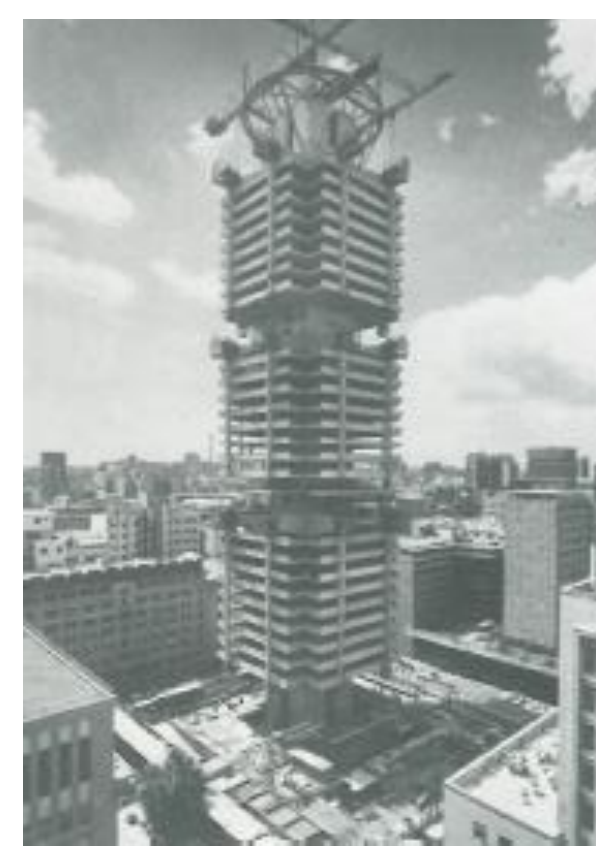

Figure 12. Progress Photograph: March 1969

Source: J.G. Boss from Hentrich 1970, 46.

The construction process was made possible by a number of ingenious solutions devised to solve many of the unique problems resulting from the novel building structure. In this way the building not only pushed many design boundaries but also resulted in many construction 'first-offs'. Notably, it was completed before time and within budget. ${ }^{60}$

60. Bergs, 2018 
An aspect that played a critical role in the success of the construction project was good communication and teamwork between all parties. ${ }^{61}$ If necessary, meetings were held day after day, week after week, throughout the process. Hentrich believes that "communications in the building industry is probably the one aspect which has received the least attention from the industry... and the failure to communicate successfully has almost certainly been responsible for more wasted costs, delays in construction and inefficiency than any other single factor in building." $62 \mathrm{He}$ continues by stating that, "Only by these means was it possible to ensure that the contract proceeded smoothly, that no items were left unresolved and that everyone knew without any doubt exactly what his function in the entire operation was expected to be." 63 However, the extensive use of prestressed concrete and the hanging structure, with its concomitant stresses, means that demolition is almost impossible.

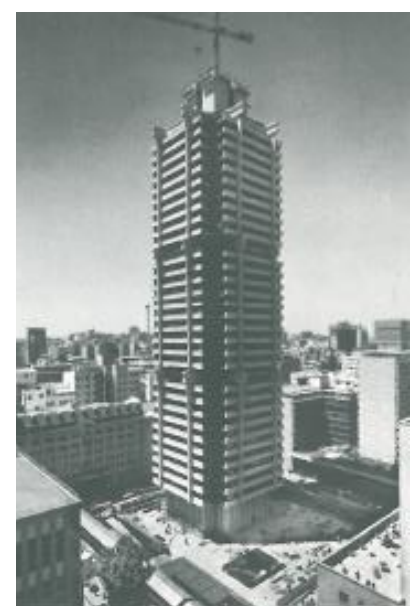

Figure 13. Progress Photograph: October 1969

Source: J.G. Boss from Hentrich 1970, 47.

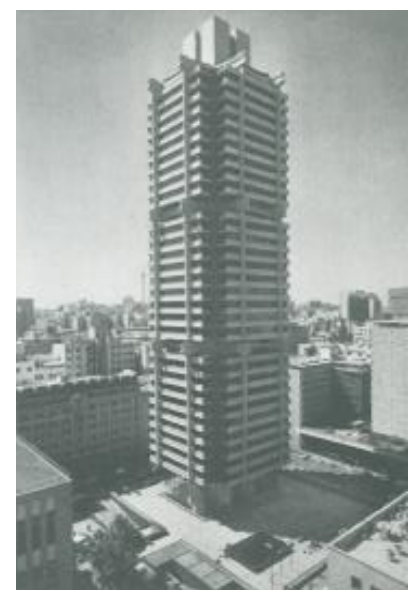

Figure 14. Progress Photograph: March 1970

Source: J.G. Boss from Hentrich 1970, 47.

61. Ibid; Hentrich, Standard Bank Centre Johannesburg, 1970, 18.

62. Hentrich, Standard Bank Centre Johannesburg, 1970, 18.

63. Ibid. 


\section{Yeang's Model for Analysing the Environmental Impact of Buildings}

'Green' is a term often used when referring to sustainable design. Ken Yeang defines 'green' or ecological design as 'building with minimal environmental impacts, and where possible, building to achieve the opposite effect; this means creating buildings which have positive, reparative and productive consequences for the natural environment, while at the same time integrating the built structure with all aspects of the ecological systems of the biosphere over its entire life cycle." 64 This more holistic approach is needed if the human species is not to overload the planet's ability to support all species and natural systems. Failure to design in this way will result in the total devastation of our natural and built environments. ${ }^{65}$ Yeang's approach is far closer to the Bruntland definition than that of Foster and Partners. Furthermore, Yeang developed a model (Figure 15) that can be used to assess the sustainability of a particular building's design. While this model was published as far back as 1999, it remains relevant to this day. Furthermore, his model emphasises passive design, rather than the active systems that have gained prominence since then. It is important to note that because the analysis considers a building started 33 years earlier, any model that places much emphasis on active systems would not be suitable.

For the foregoing reasons, this model will be used to assess the extent to which the building complies with green design principles of the Standard Bank Centre in order to assess the extent to which the building's design contributed to its present state.

Yeang considers that "a building exists both in terms of its physical being (form, siting and structure) and its functional aspects." ${ }^{\circ 6}$ Both of these aspects constitute a relationship between the built structure and the natural environment, a relationship that takes place during the lifespan of the structure. Therefore, the building functions as a living organism that consumes energy and materials instead of food, while emitting outputs into its environment. This concept of the building as an open system was developed into a "partitioned matrix" which combines these sets of interactions into a single model illustrated in Figure 15. The designer must use the partitioned matrix to consider his/her design in terms of its component parts: inputs, outputs, internal relations, external relations and how these interact with each other.

However, more importantly, he emphasises the need for all design to be regarded in the context of the complete life-cycle of the building, from the sourcing of materials and manufacture of components to the eventual demolition of the building and the reuse/recycling of the materials and energy embodied in it. ${ }^{67}$ This calls for a much deeper and more holistic, ultra-long-term analysis - far more than the pitiful feasibility study carried out before the start of this project. ${ }^{68}$

64. Yeang, The Green Skyscraper: The Basis for Designing Sustainable Intensive Building, 1999, 8.

65. Ibid, 8.

66. Ibid, 63.

67. Ibid, 51.

68. Hentrich, Standard Bank Centre Johannesburg, 1970, 16. 


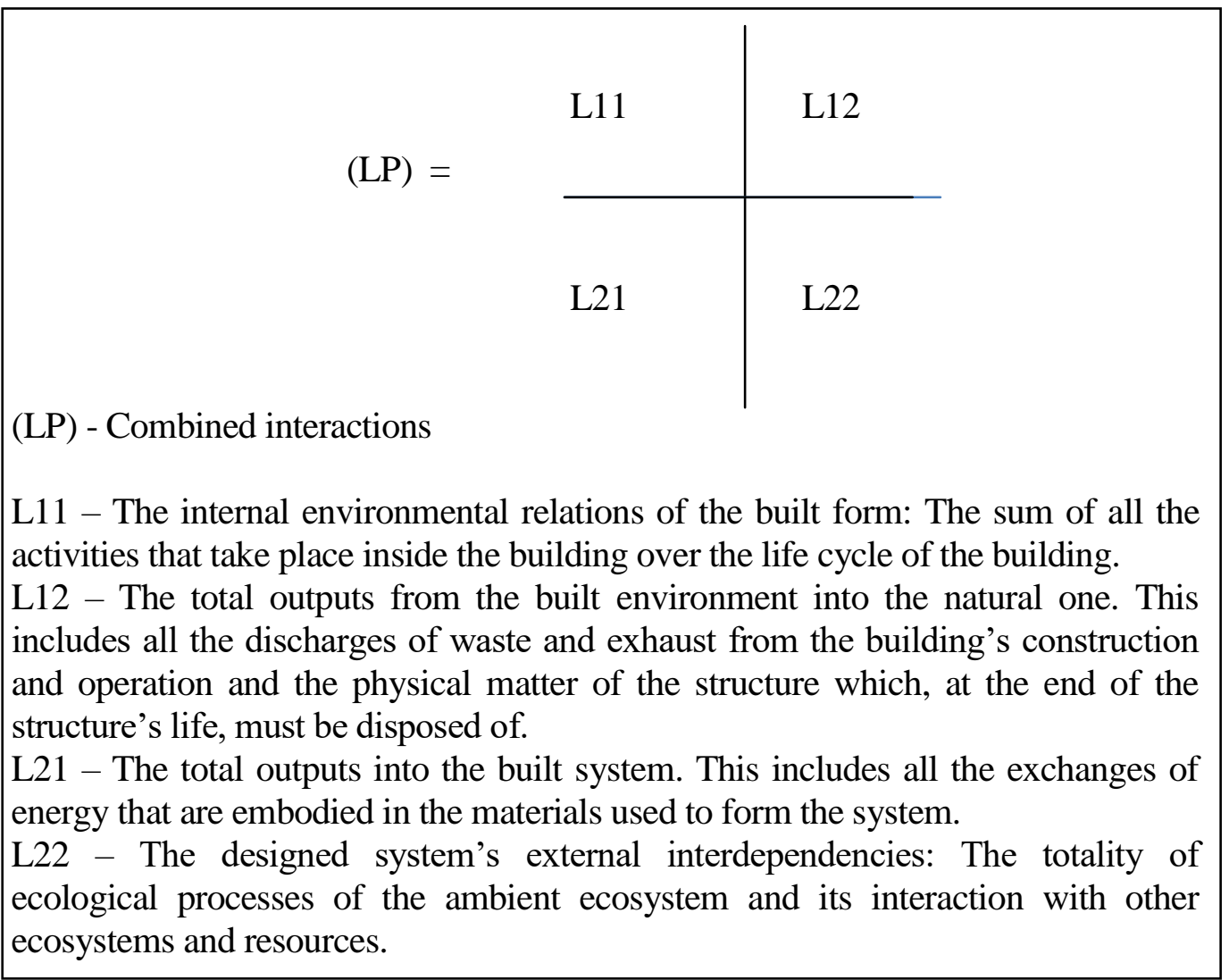

Figure 15. Yeang's Partitioned Matrix ${ }^{69}$

\section{L22: External Interdependencies}

The site for the Standard Bank Centre is in a built-up area and was largely covered by older buildings before the project started. The existing buildings were demolished and it is not known what happened to the materials obtained during the process. It is assumed that they would have been transported to a landfill-site since recycling was not common at the time. No evidence of any trees or other vegetation on the site before construction commenced could be found. From photographs (Figure 16) it would appear that the entire area was covered. ${ }^{70}$ As part of the project, the erstwhile Hollard Street was closed and replaced by a 'garden.' ${ }^{71}$ It is not known what species of plants were planted in this area and if they were endemic to the Johannesburg area.

The only planting introduced as part of the project were long narrow plant boxes used to demarcate the edges of the property and to retain soil on the sides where the piazza is lower than the surrounding ground level (Figure 3). Planting of trees would have been complicated by the basements that covered the entire site.

69. Yeang, The Green Skyscraper: The Basis for Designing Sustainable Intensive Building, $1999,65$.

70. Hentrich, Standard Bank Centre Johannesburg, 1970, 12.

71. Ibid, 11. 
However, the result is that the public space that formed the core concept of the design ended up devoid of substantial greenery that could provide welcome shade, soften the harsh urban environment and act as windbreaks. Importantly, if trees were included in the design, it could have contributed to a linking of ecosystems, albeit on a limited scale, and in creating a space that is more inviting to passers-by.

The decision to minimise the footprint of the tower block is a positive aspect because it creates a much-needed open space and allows sunlight into the public space. Furthermore, the building was positioned to minimise the impact its shadow would have on adjoining properties. While this can be commended, no attempt was made to collect and reuse rainwater or to channel it in ways that will maintain natural drainage patterns. Likewise, the square form of the building meant that the building was not oriented to maximise the benefits of the northern aspect or to minimise exposure to the negative implications of the eastern and western aspects. The envelope on all four sides is identical and overhangs with tinted glass and vertical blinds are used on all sides. This must have resulted in the rooms on the eastern and western sides overheating in the mornings or afternoons and/or high operating costs associated with cooling during summer. To make the situation worse, the entire building is air conditioned and no windows can be opened. Loose plant boxes form part of the interior design providing some relief.

From the foregoing it is clear that with the exception of the positioning of the building on the site, no attention was given to external interdependencies.

\section{L21: The Total Outputs into the Built System}

Construction started in April $1966 .^{72}$ The first steps involved the demolition of the existing buildings. The materials that could be harvested, as far as can be ascertained, were not reused or recycled (something that was not practice at the time). Hence, all the energy and resources embodied in those buildings were lost.

Looking past the loss of embodied energy, the demolition of these buildings, some of which had heritage value such as the renowned Cullinan Building by Leck and Emley, also resulted in the loss of valuable urban assets which should have been retained for their historical value (Figure 16.) ${ }^{73}$

The new building was constructed with the extensive use of reinforced concrete and pre-stressed lightweight concrete. Other materials used extensively, were glass (laminated and toughened), anodised aluminium, steel (mild and stainless), fibre-glass insulation, neoprene gaskets, gypsum board, vinyl and asbestos (in the vinyl-asbestos floor tiles and as part of the partition walls.) ${ }^{74}$

72. Ibid, 18

73. J. J. Bruwer, Heritage Assessment Surveying Form: Standard Bank Towers (Unpublished Heritage Assessment, 2002), 4.

74. Hentrich, Standard Bank Centre Johannesburg, 1970. 


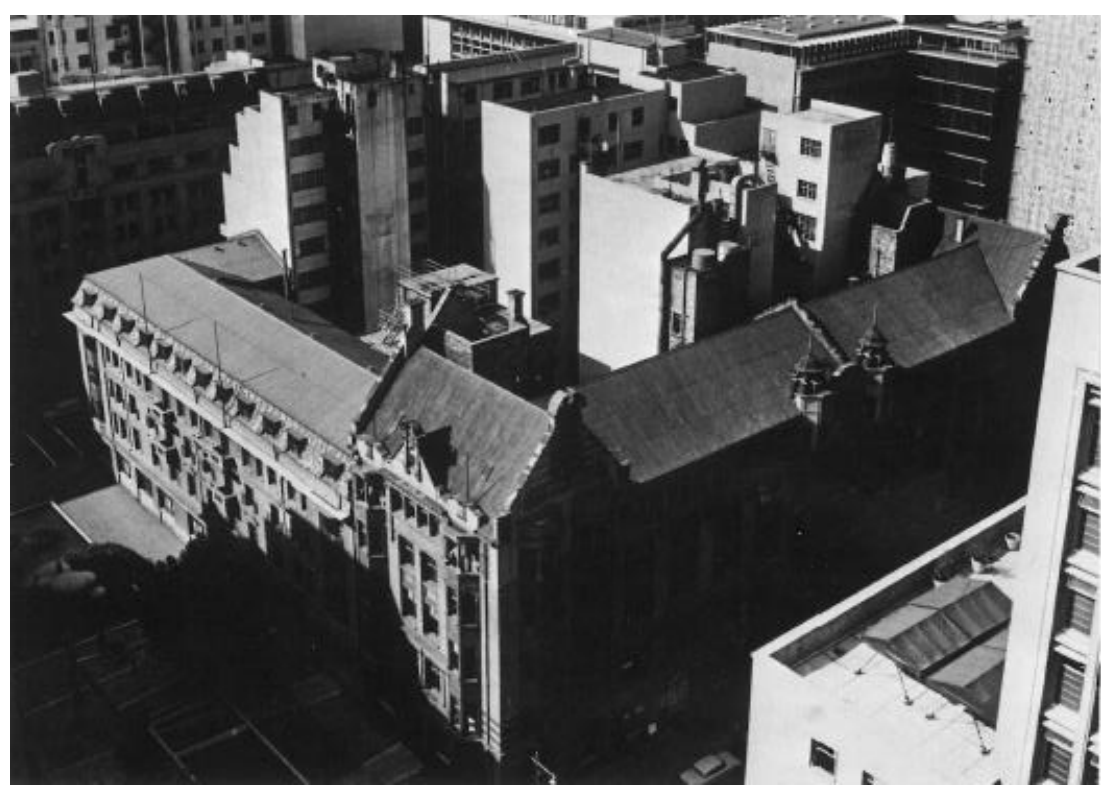

Figure 16. The Site before Demolition with the Cullinan Building on the Right Source: D. Franzke from Hentrich 1970, 12.

When compared with embodied energy figures the extensive use of concrete, commendably, resulted in relatively low levels of captured embodied energy. What is alarming is the use of plastics (vinyl and neoprene) and even more so, the extensive use of asbestos. However, the positives associated with the extensive use of concrete are diminished by the fact that most of it is used in prestressed panels, and in a post-stressed and hanging building structure that massively complicates demolition and harvesting. ${ }^{75}$ Furthermore, the extensive use of asbestos and the imperative to remove it from the building will have serious cost implications for any attempt at refurbishment.

The foregoing indicates that thorough lifecycle planning and the implications of the embodied energy levels were not considered as part of the design (common practice at the time). However, in hindsight this aspect should have received more attention.

\section{L11: The Internal Environmental Relations of the Built Form}

When considering the sum of all the activities that take place inside the building over its life cycle, the aim should be to determine the extent to which the design optimises the use of all passive means of controlling the interior environmental conditions. The aim should be to create comfortable environmental conditions with the smallest possible use of energy. ${ }^{76}$ Much of this has always been part of good design and architects cannot claim that these aspects were not important in 'those days'. However, to achieve this and create high performance buildings, the complete integration of architecture and engineering is of pivotal

75. Occupational Safety and Health Academy, Course 815 - Demolition Safety (2017), 4.

76. Yeang, The Green Skyscraper: The Basis for Designing Sustainable Intensive Building, 1999, 197. 
importance. ${ }^{77}$ The expense associated with sustainable design will then be recouped from lower running costs. ${ }^{78}$

Ali and Armstrong believe that such an integrated process is required because green design impacts many aspects of a building. This includes aspects such as daylighting (a factor of siting, orientation, building form, façade design, interior finishes, lighting and cooling loads, ${ }^{79}$ floor layouts and ventilation.

Johannesburg is also regarded as one of the cities with the most comfortable subtropical climatic conditions, moderated by its high altitude (1 750 meters above Mean Sea level. $)^{80}$ Hence, right at the outset, the decision to use air-conditioning throughout the building and not have any windows that can open must be criticised. However, the architects' failure to develop a more appropriate environmental design does not end there. The aspect ratio of the square building (1:1) is not suited for this environment where aspect ratios of between 1:16 and 1:3 would be more appropriate. ${ }^{81}$ As was pointed out earlier, matters were made worse by the 'one solution fits all' treatment of all facades without any recognition given to the different orientations' exposure to the hot morning or afternoon sunlight (the average annual amount of sun hours in Johannesburg is 3182 or 8.42 hours per day) ${ }^{82}$ and the potential impact thereof on the comfort of the inhabitants or on the cooling loads imposed on the air-conditioning system.

Despite the perceived advantages of core structural systems, ${ }^{83}$ the situation is further compromised by the decision to locate all the major service ducts and movement systems in the centre of the building (as they often are in skyscrapers) (Figure 5). Central core layouts result in significantly higher cooling loads. ${ }^{84} \mathrm{Had}$ they been placed at the eastern or western ends of the building (as in Norman Foster's Hong Kong Shanghai Bank, also a 'hanging building') (Figure 2) they could have served to reduce the cooling load, apart from the many other advantages of such arrangements. ${ }^{85}$ Furthermore, central cores also result in inflexible layouts, something that can diminish the lifespan of the building, thereby drastically increasing the energy and resources wasted. It also meant that the deep-space offices which Prof. Mallows called for could not be realised. Also, it is a direct contravention of the 'flexible' principal, highlighted by Foster and Partners. Sassi summarises by stating that "getting the building configuration and structure right makes the largest contribution to creating low energy buildings. $" 86$

77. Ali and Armstrong, "Overview of Sustainable Design Factors in High-Rise Buildings," 2008, 3 .

78. Ibid.

79. Ibid.

80. Climates to Travel, Climate - Johannesburg: Average Weather, Temperature, Rainfall, Sunshine Hours ([s.a.]), [sp].

81. Yeang, The Green Skyscraper: The Basis for Designing Sustainable Intensive Building, 1999, 205

82. World Weather and Climate Information.

83. Gültekin and Yavaşbatmaz, "Sustainable Design of Tall Buildings," 2013, 451.

84. Yeang, The Green Skyscraper: The Basis for Designing Sustainable Intensive Building, 1999, 208.

85. Ibid, 209.

86. Sassi, Strategies for Sustainable Architecture, 2006, 207. 
One of the potential benefits of this type of floor-layout is that the proximity to the perimeter enjoyed by most areas could be used to reduce the energy load induced by lighting. ${ }^{87}$ However, once again, the designers adopted a simplistic 'one size fits all' approach with lighting distributed evenly across the entire area regardless of orientation or distance from the perimeter windows.

On the positive side the designers also took steps to reduce the energy load of the building. The biggest of these was to incorporate two thermal storage systems to serve all the air handling plants. Energy costs were reduced by heating the water in these tanks during the night when the unit costs of electricity dropped. Secondly, the design of the ground and lower ground floors created a triple volume space which connected the banking hall with the ground floor, thereby allowing natural daylight, streaming in through the glass screen that enclosed the space, to also stream into the banking hall, in turn reducing the lighting that had to be installed.

\section{L12: The Total Outputs from the Built Environment into the Natural One}

This includes all the discharges of waste and exhaust from the building's construction and operation, and the physical matter of the structure which, at the end of the structure's life, must be disposed of. As indicated above, these aspects received no attention from the designers. Similarly, no attention was paid to the possible reuse of grey water in order to minimise the impact the building will have on the environment.

Furthermore, it must be remembered that the extensive use (wastage) of electricity will have a negative impact on the environment in a country that still relies on coal for generating most of its electricity. In addition, the extensive use of asbestos means that asbestos fibre, long shunned for its negative impact on health, continue to be released into the environment.

\section{Conclusions and Recommendations}

With the benefit of hindsight, the foregoing analysis shows that this much admired, elegant building, despite all the technological advances it embodied, and all the attention it attracted, fails when considered from a green design perspective, and that this has contributed to its current state. The design did not result in a sustainable building from any particular understanding of sustainability. Thus, it is not surprising that it stands as a hardly used historic artefact in the centre of Johannesburg.

While it is true that many of the city's businesses moved out of the central area, as mentioned by Clive Chipkin in the Research Methodology Section, it is noteworthy that when the Standard Bank decided to build a new headquarters building in 1978 (only eight years after moving to the Standard Bank Centre!) they chose to remain in the central city, as did some of the other major South African

87. L. S. Beedle, M. M. Ali, P. J. Armstrong, The Skyscraper and the City: Design, Technology and Innovation (New York: Edwin Mellen Press, 2007), 54. 
banks. However, this was not the main reason for their eventual move out of the building.

Interestingly, the brief for their new building called for:

- A low-rise building which allowed for quick and easy vertical movement.

- A deep-space layout which would provide a completely flexible office layout system.

- A mass thermal storage system for greater energy efficiency. ${ }^{88} /^{89}$

Clearly the bank had learned a lesson, i.e. superficial feasibility studies are not enough and buildings must be designed to ensure their sustained use. Planning and feasibility studies should consider the entire life-cycle of the building, as proposed by Yeang. ${ }^{90}$ Noteworthy is that the new Standard Bank building was recognised for its focus on low-energy consumption and remains one of the bank's main operational centres in Johannesburg. Thus, because the future is difficult to predict, flexibility and adaptability remain critical aspects that will extend the usable lifetime of any building.

What this furthermore indicates is that even 'vanity projects' must follow green design principles to enhance their financial sustainability. If not, then the same sad future might await those buildings. While keeping the period during which the building was designed in mind, the foregoing analysis showed that the main causes of the building's current state is the simplistic concept which adopted a single design solution for all the sides of the building, failure to recognise the advantages that Johannesburg's mild climate could provide, coupled with the central core layout which resulted in an 'inflexible' floor layout. Despite this, new skyscraper developments are still designed using this type of layout. Examples are London's One Blackfriars and Strata SE1 buildings. If the case of the Standard Bank Centre is kept in mind, buildings designed in this way must be approached with care.

Furthermore, planning for financial or investment sustainability must include planning for environmental sustainability in line with 'green' guidelines, not merely because tenants might insist on it, but because the two go hand in hand.

\section{Bibliography}

Ali, M. M. and P. J. Armstrong. "Overview of Sustainable Design Factors in High-Rise Buildings." Paper Delivered at the Council on Tall Buildings and Urban Habitat $8^{\text {th }}$ World Congress, Dubai, 2008.

Al-Kodmay, K. Eco-Towers: Sustainable Cities in the Sky. Southhampton: WIT Press, 2015.

88. Standard Bank, "Superblock”: The Standard Bank Administration Building (Unpublished Booklet. Supplement to Planning and Building Developments, September/October 1982), 8.

89. Interestingly, the building was designed by Prof. Mallows' own firm: Mallows, Louw, Hoffe and Partners.

90. Yeang, The Green Skyscraper: The Basis for Designing Sustainable Intensive Building, 1999, 18. 
Archdaily. Munich Olympic Stadium, 2018. Retrieved from: https://bit.ly/2kn55Xm. [Accessed 12 December 2018].

Beedle, L. S., M. M. Ali, P. J. Armstrong. The Skyscraper and the City: Design, Technology and Innovation. New York: Edwin Mellen Press, 2007.

Bergs, H. Architect. Former Partner in the Firm Heintrich, Bergs and Associates. Personal Interview. Johannesburg, 2 October, 2018.

Boote, D. N. and P. Beile. "Scholars Before Researchers: on the Centrality of the Dissertation Literature Review in Research Preparation." Educational Researcher 34, no. 6 (2005): 3-15.

Bruwer, J. J. Heritage Assessment Surveying Form: Standard Bank Towers. Unpublished Heritage Assessment, 2002.

Cambridge Dictionaries. Cambridge Business English Dictionary. Cambridge University Press [s.a.]. Retrieved from https://bit.ly/2BuanWn. [Accessed 4 February 2019].

Chipkin, C. M. Johannesburg Style: Architecture and Society 1880s-1960s. Cape Town: David Philip, 1993. . Johannesburg Transition: Architecture and Society from 1950. Johannesburg: STE, 2008.

Climates to Travel. Climate - Johannesburg: Average Weather, Temperature, Rainfall, Sunshine Hours. [s.a.]. Retrieved from https://bit.ly/2mjHuHD. [Accessed 1February 2019].

Del Percio, S. T. "The Skyscraper, Green Design and the LEED Green Building Rating System: The Creation of Uniform Sustainable Standards for the $21^{\text {st }}$ Century or the Perpetuation of an Architectural Fiction.” In Environs: Environmental Law and Policy Journal 28, no. 1 (2004): 117-154.

Duprè, J. Skyscrapers: A History of the World's Most Extraordinary Buildings. New York: Black Dog \& Leventhal, 2013.

Edwards, B. Rough Guide to Sustainability: A Design Primer. $4^{\text {th }}$ Edition. London: RIBA Publishing, 2014.

Gültekin, A. B. and S. Yavaşbatmaz. "Sustainable Design of Tall Buildings." In Gradevinar 65, no. 5 (2013): 449-461.

Hentrich, H. Standard Bank Centre Johannesburg. Johannesburg: Standard Bank Investment Corporation, 1970.

Höweler, E. Skyscraper: Designs of the Recent Past and for the New Future. London: Thames \& Hudson, 2003.

Jenks, C. Late-Modern Architecture and Other Essays. London: Academy Editions, 1980.

Lepik, A. Skyscrapers. Munich: Prestel, 2008.

Lubitz, J. Architecten-Portrait: Helmut Hentrich 1905-2001. 2005. Retrieved from: http:// architekten-portrait.de/helmut_hentrich/index.html. [Accessed 11 January 2019].

Occupational Safety and Health Academy. Course 815 - Demolition Safety. 2017. Retrieved from: https://bit.ly/2lYCdoZ. [Accessed 31 January 2019].

Sassi, P. Strategies for Sustainable Architecture. New York: Taylor \& Francis, 2006.

Schierle, G. D. Suspend High-Rise. 2012. Retrieved from: https://bit.ly/2mi6A9R. [Accessed 12 December 2018].

Standard Bank. "Superblock": The Standard Bank Administration Building. Unpublished Booklet. Supplement to Planning and Building Developments, September/October 1982.

Watts, S. “Can Skyscrapers be Sustainable?" In The Council on Tall Buildings and Urban Habitat Journal 2, no. 68 (2013).

World Weather and Climate Information. Average Monthly Hours of Sunshine in Johannesburg (Gauteng). [s.a.]. Retrieved from: https://bit.ly/2mmvXHD. [Accessed 22 February 2019]. 
Yeang, K. Designing with Nature: The Ecological Basis for Architectural Design. New York: Mcgraw-Hill, 1995.

. The Green Skyscraper: The Basis for Designing Sustainable Intensive Buildings. Munich: Prestel Verlag, 1999.

. The Green Skyscraper: The Basis for Designing Sustainable Intensive Buildings. New York: Prestel, 2000.

Reinventing the Skyscraper: A Vertical Theory of Urban Design. Chichester: Wiley Academy Press, 2002.

Eco Skyscrapers Volume 1. Edited by Ivor Richards. Victoria: Images Publishing, 2007.

Yeang, K and L. Bullivant. Eco Skyscrapers Volume 2. Victoria: Images Publishing, 2011.

Zaknic, I., M. Smith, D. Rice. 100 of the World's Tallest Buildings. Victoria: Images Publishing, 1998.

Zunz, G. J., R. A. Heydenrych, D. Michael. "The Standard Bank Centre, Johannesburg." In Die Siviele Ingenieur in Suid Afrika. February 1971. 